This item was submitted to Loughborough's Research Repository by the author.

Items in Figshare are protected by copyright, with all rights reserved, unless otherwise indicated.

\title{
Teammate influences on the eating attitudes and behaviours of athletes: A systematic review
}

\section{PLEASE CITE THE PUBLISHED VERSION}

https://doi.org/10.1016/j.psychsport.2019.02.006

\section{PUBLISHER}

(C) Elsevier

\section{VERSION}

AM (Accepted Manuscript)

\section{PUBLISHER STATEMENT}

This paper was accepted for publication in the journal Psychology of Sport and Exercise and the definitive published version is available at https://doi.org/10.1016/j.psychsport.2019.02.006

\section{LICENCE}

CC BY-NC-ND 4.0

\section{REPOSITORY RECORD}

Scott, Charlotte L., Emma Haycraft, and Carolyn Plateau. 2019. "Teammate Influences on the Eating Attitudes and Behaviours of Athletes: A Systematic Review”. figshare. https://hdl.handle.net/2134/36966. 
Teammate influences on athletes' eating attitudes and behaviours

3

4

5

6

7

8 (1)

8

\section{Teammate influences on the eating attitudes and behaviours of athletes:}

\section{A systematic review}

(1)

Charlotte L Scott ${ }^{\mathrm{a}}$, Emma Haycraft $^{\mathrm{a}}$ \& Carolyn R Plateau $^{\mathrm{a} *}$

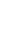

${ }^{\text {a }}$ School of Sport, Exercise and Health Sciences, Loughborough University, LE11 3TU, UK

*Corresponding author. School of Sport, Exercise and Health Sciences, Loughborough University, Loughborough, LE11 3TU, UK. E-mail address: C.R.Plateau@1boro.ac.uk. Telephone number: +44 (0)1509 228487

$$
\text { Fax: }+44(0) 1509226301
$$

Funding: Charlotte L Scott is funded by a PhD studentship awarded by the School of Sport, Exercise and Health Sciences at Loughborough University, UK.

\section{Declarations of interest: None}


Teammate influences on athletes' eating attitudes and behaviours

\section{Teammate influences on the eating attitudes and behaviours of athletes:}

\section{A systematic review}

\section{Abstract}

Background: It has been well documented that athletes are at an increased risk of developing disordered eating attitudes and behaviours. Over the last two decades, researchers have focused their attention on how teammates may influence athletes' eating attitudes and behaviours. Objective: To systematically review the literature relating to teammate influences on athletes' eating attitudes and behaviours. Method: A systematic literature search of the SPORTDiscus, PsycINFO and MEDLINE databases was conducted. Qualitative and quantitative studies were included if they met the following inclusion criteria: (1) examined the relationship between teammate influence and eating attitudes and/or behaviours; (2) sampled actively training athletes; (3) written in English; and (4) published in a peer-reviewed academic journal. Results: Twenty-four studies were included ( $n=13$ quantitative, $n=11$ qualitative). Included studies were found to be of good or reasonable quality. Mechanisms of influence were categorised as (1) Teammate support (e.g., supportive teammate friendships, promotion of healthy eating practices, vigilance against disordered eating), and (2) Teammate pressure (e.g., conflicting teammate friendships, critical comments and appearance conversations, maladaptive team norms, and competitive comparisons).

Conclusion: Teammates are an important source of influence on athlete eating attitudes and behaviours and these influences can be protective against, or engender an increased risk for, disordered eating. Additional, prospective research is required to enhance understanding of the mechanisms of teammate influences and to inform the development of interventions to reduce disordered eating among athletes.

Key words: Disordered eating; Wellbeing; Sport; Social comparison; Social norms; Athlete 
Teammate influences on athletes' eating attitudes and behaviours

Teammate influences on the eating attitudes and behaviours of athletes: A systematic review

47 Eating attitudes (beliefs, thoughts and feelings around food) and eating behaviours (discussions, actions towards and relationships with food) are broad constructs that can influence people's food choices and preferences, as well as their wider health and wellbeing (Neumark-Sztainer, Story, \& Casey, 1999; Sun, 2008). Eating attitudes and behaviours are known to exist on a continuum from normal eating (e.g., the consumption of a nutritionally balanced diet with healthy attitudes and behaviours towards food) through to disordered eating. Disordered eating encompasses abnormal attitudes and behaviours towards food and weight control, such as the restriction of food intake, the use of laxatives and diuretics, bingeing and purging behaviours (Nattiv et al., 2007) as well as a pre-occupation with weight, shape and appearance (Fairburn, Cooper, Shafran, \& Wilson, 2008). Prevalence rates for disordered eating attitudes and behaviours are elevated among athletic populations, with estimates between 14-45\% (Petrie, Greenleaf, Reel, \& Carter, 2008; Martinsen et al., 2010).

Disordered eating is a significant risk factor for the development of clinically significant eating disorders (ED) in athletes (Sundgot-Borgen, 1994). While few studies have established ED prevalence in athletes, in one large-scale study, $20 \%$ of female athletes and $8 \%$ of male athletes were established as having an ED (primarily BN or OSFED) via clinical interview (Sundgot-Borgen \& Torstveit, 2004). In the general population, sociocultural influences (e.g., from the media, family and friends) have been identified as playing a key role in the development of disordered eating. This is suggested to be facilitated by social comparison (comparing others' eating attitudes and behaviours to one's own, to the perceived norm, or to the person/people you hope will see you in a favourable light; Polivy \& Pliner, 2015) and self-objectification (viewing oneself in the eyes of the observer), whereby influences from others affect how people define themselves and the role of food in their lives (Smolak \& Chun-Kennedy, 2015). 
Teammate influences on athletes' eating attitudes and behaviours

In addition to these general influences, evidence suggests that athletes are at an increased risk of disordered eating compared to nonathletes (e.g., Sundgot-Borgen, 1993; Sundgot-Borgen \& Torstveit, 2004). This may be due to specific sport-related pressures to achieve a particular physique. For example, for certain sports (e.g., cheerleading, figure skating), athletes are judged on how their body is presented in a uniform in addition to their performance (Reel \& Gill, 1996). Furthermore, athletes may also experience pressure from their coaches and teammates to lose weight/change shape (Petrie, Greenleaf, Carter, \& Reel, 2007), especially if information regarding body weight is made publicly available via team weigh-ins (Galli, Petrie, \& Chatterton, 2017). Aside from these external pressures, individual athletes may also perceive a performance advantage to competing at a lower weight. This is typically the case for athletes competing in combat sports who often train above their weight class and engage in rapid weight loss techniques prior to a competition with the view to improve chances of success (Franchini, Brito, \& Artioli, 2012). In combination, these weight and shape related pressures encountered by athletes may serve to increase the risk of the development of disordered eating above and beyond the risk for nonathletes.

Sociocultural influences and the nature of the social setting when eating are also known to have an important impact on individuals' attitudes towards food and food choice / intake (Herman \& Higgs, 2015). For example, there is evidence to suggest that individuals are likely to modify their food choice and intake depending not only on who they are eating with, but also the eating patterns of these companions. Eating behaviour and attitude changes can occur through modelling (imitation of attitudes and behaviours towards food; Cruwys, Bevelander, \& Hermans, 2015; Stice, 1998), social facilitation (eating more as a result of eating with others; Herman, 2015), impression management (modifying attitudes towards food and food choice / intake in order to make a good impression; Stoeber, Madigan, Damian, Esposito, \& Lombardo, 2017; Vartanian, 2015), and adhering to perceived social norms regarding acceptable food choice and intake patterns (Higgs, 2015). These 
Teammate influences on athletes' eating attitudes and behaviours

mechanisms of influence may be particularly relevant in certain sporting contexts (e.g., for athletes involved in a residential training program or those competing at the collegiate level who regularly eat with their teammates (Smart \& Bisogni, 2001).

A growing body of research has investigated social influences on the eating attitudes and behaviours of athletes, with teammates identified as a particularly important source of influence. For example, teammates have often been identified as having a negative influence on athletes' eating attitudes and behaviours, through normalising disordered eating attitudes and behaviours (Arthur-Cameselle \& Quatromoni, 2011), making critical comments regarding weight/shape (Muscat \& Long, 2008), and promoting body weight and shape comparison and competition (Thompson \& Sherman, 2011). However, teammates can also act as a positive influence, for example through the provision of anti-dieting advice to peers (Kroshus, Kubzansky, Goldman, \& Austin, 2015), challenging team members who engage in "fat talk" (Smith \& Ogle, 2006), and by establishing healthy eating attitudes via positive team norms (Kroshus, Goldman, Kubzansky, \& Austin, 2014).

Research has traditionally focused on female athlete experiences of sociocultural pressures around weight, shape and appearance (e.g., Petrie, Greenleaf, Reel, \& Carter, 2009; Reel \& Gill, 1996). More recently however, research has revealed that male athletes also report experiencing sociocultural pressures regarding their body weight and shape (Galli \& Reel, 2009). The nature of these pressures may manifest differently, with evidence to suggest a desire for muscularity and leanness among male athletes, versus thinness among female athletes (Bryne \& McLean, 2002; Galli \& Reel, 2009). In the general population, weight control methods also vary by gender, with evidence to suggest that males are more likely to report using exercise to increase body size whereas females are more likely to engage in restriction to reduce body size (McCabe \& Ricciardelli, 2001; Ridgeway \& Tylka, 2005). 
Teammate influences on athletes' eating attitudes and behaviours

121 Therefore, it is plausible that the nature of influences from teammates regarding athletes' eating attitudes and behaviours may differ as a function of gender.

Despite rapidly growing interest in social influences on athletes' eating attitudes and

124 behaviours, there has not yet been a systematic review of the literature which explores the

125 influences of teammates. Existing reviews have primarily focused on how parents or coaches 126 can influence athlete eating attitudes and behaviours (e.g., Thompson \& Sherman, 2011) but

127 it is noteworthy that parental influence on young athletes has been suggested to diminish

128 beyond the age of 13 (Wylleman \& Lavallee, 2004). In the general population, peers have

129 been identified as the primary source of social support from adolescence onwards

130 (Friedlander, Reid, Shupak, \& Cribbie, 2007). Given that in athletic populations peer

131 friendships (e.g., with teammates/training partners) tend to be particularly strong (Smith,

132 2007; Weiss, Smith, \& Theeboom, 1996), conducting a comprehensive review of the

133 teammate influence literature in relation to eating attitudes and behaviours is essential. The

134 primary aim of this review was to synthesise existing findings in order to address two key

135 research questions: first, what are the mechanisms by which teammates might influence

136 athletes' eating attitudes and behaviours? Second, where is further research or investigation

137 required?

\section{Method}

\section{Search strategy}

140 Preferred Reporting Items for Systematic Reviews and Meta-Analyses (PRISMA) guidelines

141 were followed to undertake this systematic review (Moher, Liberati, Tetzlaff, Altman, \&

142 Group, 2010). In order to obtain relevant peer-reviewed articles, an electronic literature

143 search was conducted using the PsycInfo, SportDiscus and PubMed databases. Retrieved

144 papers were published up to January 2018. Within each search engine, terms were entered in

145 relation to athletes (e.g., athlete, player, sport) and these were combined with terms relating

146 to disordered eating behaviours and attitudes using the "AND" Boolean operator (e.g., eat, 
Teammate influences on athletes' eating attitudes and behaviours

147 diet, weight control). Where relevant, the * wildcard function was used with the stem of

148 words, ensuring that every possible variant was identified in the searches.

\section{Inclusion and exclusion criteria}

150 To be considered eligible for inclusion, articles had to be written in English and be published

151 within peer reviewed academic journals. Included articles were required to assess the

152 relationship between teammate influences (defined as the ways in which an athletes' attitudes

153 and behaviours are affected by the actions of their teammates e.g., via team norms,

154 modelling, relationship quality, pressures and discussions around weight/shape and food,

155 (Paxton, 1996)) and eating attitudes (e.g., any thought, belief or emotional response towards

156 food) and/or behaviours (e.g., food preference, quantity of food intake, controlling weight via

157 food restriction), in currently active athlete populations. For the purpose of this review, our

158 definition of eating attitudes or behaviours did not consider exclusively nutritional practices

159 (e.g., the consumption of dietary/performance enhancing supplements or adherence to

160 specific diets). Criteria (Araújo \& Scharhag, 2016) were used to determine whether the

161 studies were conducted with currently active athlete populations. Studies were required to

162 report that their participants met at least one of the following criteria: "actively participating

163 in sport competitions", "training in sports aiming to improve his/her performance/results",

164 and/or "have sport training and competition as his/her major activity or focus of personal

165 interest". Studies were also assessed against the athlete categorisation framework (Swann,

166 Moran, \& Piggott, 2015) to determine the competitive level of athletes across different sports.

167 Case studies or discussion/review/position statement papers were excluded.

168 Quantitative studies were excluded if they did not provide an adequate description of the

169 method used to assess teammate influence or if they used a combined score (e.g., studies

170 using scales that combined teammate, family and media influences, and which therefore did

171 not allow for the specific extraction of teammate influence data). Studies that described either 
Teammate influences on athletes' eating attitudes and behaviours

172 teammate influences or eating attitudes and/or behaviours of athletes but did not assess the

173 relationship between the two concepts were also excluded. Qualitative studies that did not

174 report a specific theme relevant to "teammate influence" were excluded. The first author

175 reviewed and selected the articles according to the agreed inclusion criteria. Uncertainty over

176 inclusion was discussed among the wider research team. The article selection process is

177 detailed in Figure 1.

\section{Quality assessment}

In order to determine the methodological quality of studies included in this review, the National Institute of Health and Clinical Excellence (NICE, 2012) checklists for qualitative studies and cohort studies and Gilbert's (Gilbert, 2009) checklist for assessing the quality of cross-sectional studies were employed. For each study, the checklists (Gilbert, 2009; NICE, 2012) were consulted as appropriate and each criterion was rated as: well covered; adequately covered; poorly covered; not addressed; not reported; or, not applicable. Furthermore, each study was given an overall rating (NICE, 2012): a) Good quality (++) (all or most of the criteria have been satisfied, unsatisfied criteria are very unlikely to change conclusions); b) Reasonable quality $(+)$ (some criteria have been satisfied, unsatisfied criteria are unlikely to change conclusions ); or, c) Poor quality (-) (few or no criteria satisfied, conclusions are likely or very likely to change).

\section{Results}

\section{Summary of included studies}

Characteristics of the 24 studies included in this systematic review are reported in

Table 1 (quantitative studies; cross-sectional, $n=12$, longitudinal, $n=1$ ) and Table 2

194 (qualitative studies; $n=11$ ). Eight qualitative studies collected data via semi-structured or

195 participant guided interviews, one used focus groups, and two used open-ended surveys.

196 Fifteen studies were conducted in the United States of America (USA), three in the United 
Teammate influences on athletes' eating attitudes and behaviours

197 Kingdom (UK), two in France, two in Canada, and one each in Spain and Portugal. Included 198 studies were published between 2000-2018, although the majority $(n=19)$ had been 199 published since 2008.

200 Study sample sizes varied greatly, ranging from 68 to $1445($ median $=199)$

201 participants for quantitative studies and from 8 to $131($ median $=22)$ participants for

202 qualitative studies. Half of the studies sampled exclusively female athletes $(n=12)$, five sampled exclusively male athletes and seven included both male and female participants. Six studies included athletes under the age of 18 years, 14 studies included athletes over the age of 18, while four studies included both adolescent and adult athletes (Bloodworth, McNamee, \& Tan, 2017; Shanmugam, Jowett, \& Meyer, 2013, 2014; Voelker, Petrie, Reel, \& Gould, 2018). Nine studies included athletes from a range of sport types, while six exclusively sampled aesthetic sports (e.g., gymnastics, figure skating), five sampled endurance sports (e.g., distance running) and two sampled ball game sports (e.g., baseball, hockey). Two studies reported only that athletes participated in either team or individual sports. None of the

211 included studies reported sufficient information about their sample to accurately categorise

212 athlete competition level (Swann et al., 2015).

\section{Risk of bias}

Based on the guidelines (Gilbert, 2009; NICE, 2012), the majority of studies ( $n=15)$ were rated as good quality and nine studies were rated as reasonable quality. Overall, the risk of bias in the included studies was deemed to be relatively low.

Quantitative studies $(\boldsymbol{n}=\mathbf{1 3})$. Methodological weaknesses that were common across

218 the quantitative (cross-sectional) studies included: a failure to indicate the response rate ( $n=$

219 8); a lack of identification and inclusion of key confounding variables in statistical analyses

220 (e.g., weight, age, competitive level; $n=6$ ); a lack of a clear definition of the study inclusion

221 criteria $(n=6)$; and, although all studies were deemed to use appropriate methods of

222 statistical analysis, many did not report exact $p$ values $(n=8)$. 
Teammate influences on athletes' eating attitudes and behaviours

However, numerous methodological strengths were identified which contributed to

224

225

226

227

228

229

230

231

232

233

234

235

236

237

the overall finding that these studies had a low risk of bias. For example, studies mostly

addressed an appropriate and clearly focused question $(n=12)$, with recruitment appropriate to the aims of the research $(n=13)$ and used representative cases from the population $(n=8)$.

Further to this, all quantitative studies were deemed to measure their outcome in a valid and reliable way (e.g., using pre-tested measures) and most $(n=11)$ adequately described efforts to reduce measurement bias (e.g., ensuring anonymity).

Qualitative studies $(\boldsymbol{n}=\mathbf{1 1})$. Qualitative studies employed appropriate methods of data collection $(n=11)$, provided clear reports of data analysis procedures $(n=10)$, and presented findings in a convincing manner $(n=10)$. However, only two studies met the criterion for trustworthiness, which required reflection on the participant-researcher relationship. Similarly, only four studies asked for participant feedback on transcripts/analysis. Furthermore, nine studies did not sufficiently describe their sample characteristics with regards to ethnicity or age.

\section{Measures}

Within the quantitative studies, a variety of measures were used to assess eating behaviours and teammate influences (summarised below).

Eating measures: Five standardised measures of disordered eating were employed, all of which assessed both eating attitudes and eating behaviours. The most frequently used measure was the EAT-26 ( $n=5$; Garner et al., 1982), which has been validated for use in female athletes (Doninger, Enders, \& Burnett, 2005). The EDE-Q (Fairburn \& Beglin, 2008) was administered in 2 studies. Neither used the three factor solution that has been validated with athletes (Darcy, Hardy, Crosby, Lock, \& Peebles, 2013).

Teammate measures: Six standardised measures of teammate influence were employed with each study employing only one measure of teammate influence. Two measures specifically assessed teammate influence (Anti-Dieting Advice Scale, Thompson et 
Teammate influences on athletes' eating attitudes and behaviours al., 2006; Sport Friendship Quality Scale, Weiss \& Smith, 1999) whereas the other four had only a single item or subscale relating to teammates (ATHLETE, Hinton \& Kubas, 2005; Sport-Specific Quality of Relationship Inventory, Jowett, 2009; Survey for the Theory of Planned Behaviour, Pawlak et al., 2009; Weight Pressures in Sport, Petrie et al., 2007). To date, these measures have not been widely used in the literature.

Non-validated measures. Two studies utilised non-validated measures. Engel et al. (2003) assessed eating behaviour using a "Purge", "Restriction" and "Binge" index that was developed specifically for their study. In addition, Toro and colleagues (2009) developed their own 28-item questionnaire to assess the effects of various situations and experiences typical of a dance school environment.

\section{Potential mechanisms of teammate influence}

After assessing the relationships between the teammate influence measures and eating attitude and behaviour measures, outcomes could be organised into two main categories: (1) teammate support (promoting positive eating practices) and (2) teammate pressures (promoting negative or unhealthy eating practices).

(1) Teammate support. Teammates were found to support and promote positive eating attitudes and practices via (a) supportive friendships, (b) actively promoting healthy eating practices and (c) being vigilant against disordered eating attitudes and behaviours.

(a) Supportive teammate friendships. Findings from four quantitative studies suggested that supportive relationships with teammates can positively impact eating attitudes and behaviour. For example, Scoffier, Maïano, and d'Arripe-Longueville (2010) found that a high global quality of sport friendship predicted female aesthetic athlete's perception of how well they were able to perform, which in turn predicted lower scores on the EAT-26.

273 findings in a similar sample. 
Teammate influences on athletes' eating attitudes and behaviours

In their longitudinal investigation with male and female athletes from a range of

275

276

277 sports, Shanmugam et al. (2014) found higher social support at baseline significantly correlated with lower scores on the EDE-Q six months later $(r=-0.17)$. However, these findings conflict with Shanmugam et al.'s (2013) cross-sectional study (also sampling males and females from a range of sports), which failed to identify any significant associations between teammate social support and EDE-Q scores.

(b) Promotion of healthy eating. The promotion of positive eating practices by older, or more experienced, teammates was related to positive eating practices among younger teammates, as demonstrated by findings from four qualitative studies. For example, younger female endurance athletes have been found to imitate portion sizes (Stickler, Armstrong, Polso, \& Smith, 2016) and eat low-fat foods/avoid drinking carbonated beverages after observing these behaviours among older teammates (male ball game athletes, Smart \& Bisogni, 2001). It is also apparent from these studies that senior teammates are aware of the impressionability of their younger teammates and so take active steps to protect them from the development of eating psychopathology. In one instance, "pasta parties" were organised by the senior members of a female running team to promote the acceptability of eating these foods (Smith \& Ogle, 2006). Similarly, older female gymnasts reported that they intentionally avoided holding discussions relating to their body dissatisfaction and pathological eating attitudes in front of the younger female gymnasts, with the intention of preventing them from modelling these disordered attitudes (Bloodworth et al., 2017).

However, Smart and Bisgoni (2001) note that as male ball game athletes mature and gain confidence in the athletic environment, they become more independent in their food choices and are less likely to be influenced by teammates' eating practices.

Two quantitative studies assessed the impact of implicit team norms on intentions to eat a healthful diet using the STPB (defined as a diet based on whole grains, fruits, and vegetables and moderate in fat, sugar, and sodium) provide mixed findings. For example, the 
Teammate influences on athletes' eating attitudes and behaviours

normative belief, "My teammates think I should eat a healthful diet" did not significantly correlate with the behavioural intention to eat a healthful diet in male ball-game athletes (Pawlak et al., 2009). In contrast, Karpinski and Milliner (2016) found that this normative belief significantly predicted a lower behavioural intention to eat a healthful diet in male and female athletes from a range of sports $(\beta=-0.29)$. The differences in athlete samples may be a reason for the discrepancy in findings between these two studies.

(c) Vigilance against disordered eating. There was evidence that female endurance athletes adopted specific actions to reduce or challenge disordered eating attitudes and behaviours among teammates. For example, in their qualitative study, Smith and Ogle (2006) found that some athletes assumed the role of "fat talk challengers" in a bid to minimise body dissatisfaction (and the potential for subsequent disordered eating) among their teammates. These athletes reported actively challenging teammates who they found to be engaging in "fat talk" (proclaiming dissatisfaction with weight or shape), by making validating comments to undermine or emphasise the nonsensical nature of their claims.

In a similar manner, a quantitative study (Kroshus et al., 2015) discovered that athletes frequently provided each other with anti-dieting advice. For example, athletes reported advising teammates not to diet because it is unhealthy and actively discussing reasons why dieting is dangerous. Such advice was more likely to be provided to teammates with lower BMIs and higher scores on the EAT-26. Indeed, this willingness to address potential eating concerns from teammates is further supported by outcomes from Kroshus et al.'s (2014) qualitative study where, in response to a hypothetical scenario of teammates engaging in unhealthy or problematic eating behaviours, athletes suggested they would "explicitly and pre-emptively establish healthy team norms" (p.141). These team members highlighted the importance of a meeting that took place at the beginning of the season where team values regarding healthy eating were re-iterated and a shared responsibility for being vigilant against disordered eating behaviours was created. The creation of this "team norm of 
Teammate influences on athletes' eating attitudes and behaviours

326

327

328

330

331

332

333

334

335

336

337

338

340

support for action" (p.146) meant that athletes were aware that should disordered eating behaviours occur in a team member, fellow teammates would provide support and intervene. In contrast, two qualitative studies highlighted how female endurance athletes were not vigilant, finding it difficult to take action if disordered eating behaviours were to occur in their teammates. This lack of vigilance has been described by one study as a norm of “deferential avoidance” (Smith \& Ogle, 2006, p.286). For example, Kroshus et al. (2014) highlighted that one team's normative approach was to simply "do nothing” (p.144) when suspecting a teammate to be engaging in disordered eating. Team members were concerned about appearing accusatory or inappropriate and so avoided challenging disordered eating amongst teammates. Indeed, one athlete suggested that holding such a conversation would be “taboo" (p.143).

(2) Teammate pressures. Teammates were also found to negatively influence (both directly and indirectly) athletes in relation to their eating attitudes and behaviours. Four mechanisms of teammate pressure were identified: (a) conflicting friendships, (b) critical comments and appearance conversations, (c) maladaptive team norms and (d) competitive comparisons between teammates.

(a) Conflicting teammate friendships. Four quantitative studies assessed interpersonal conflict with teammates. While conflict was not found to be linked to EDE-Q scores in a cross-sectional analysis sampling male and female athletes from a range of sports (Shanmugam et al., 2013), in their subsequent longitudinal study (employing a similar sample), Shanmugam and colleagues (2014) demonstrated that higher levels of teammate interpersonal conflict significantly, positively correlated with EDE-Q scores six months later $(r=0.19)$

There was equivocal evidence surrounding the relationship between teammate distrust and disordered eating attitudes and behaviour. Wadas and DeBeliso (2014) did not identify a significant relationship between teammate distrust and EAT-26 scores in male endurance 
Teammate influences on athletes' eating attitudes and behaviours

352 athletes, while in their assessment of female athletes from a range of sports, Hinton and

353 Kubas (2005) found that higher levels of teammate distrust significantly predicted Q-EDD

354 group membership (OR $=1.6, p=0.05)$. It is possible that this discrepancy may be due to

355 gender differences in the athletes sampled in these two studies. Distrust in teammates may be

356 more of an important factor when predicting disordered eating attitudes and behaviours for

357 female athletes, although further investigation is required to confirm this.

$358 \quad$ (b) Critical comments and appearance conversations. Three qualitative studies

359 (Arthur-Cameselle, Sossin, \& Quatromoni, 2017; Francisco, Alarcão, \& Narciso, 2012;

360 Stirling \& Kerr, 2012) identified that athletes experienced pressure from their teammates to

361 modify their weight and shape via critical comments or conversations about pathogenic

362 weight control methods. Francisco et al. (2012) found that such comments triggered

363 emotional distress and a variety of weight control behaviours among younger male and

364 female aesthetic athletes ( $<15$ years). However, Arthur-Cameselle et al. (2017) noted that in

365 their sample of female athletes from a range of sports, pressures relating to sport performance

366 were far more frequently reported as a trigger of eating disorder symptoms (reported by $67 \%$

367 of athletes) compared to negative comments received from peers (reported by $8 \%$ of

368 athletes). Athletes reported that conversations held amongst teammates where the merits of

369 different methods of pathogenic weight loss practices were discussed were particularly

370 damaging as they often resulted in the use of discussed practices (Arthur-Cameselle et al.,

371 2017).

372 (c) Maladaptive team norms. There was some evidence of the presence of

373 maladaptive team norms as well as perceived pressures from teammates in relation to

374 achieving a certain body shape/weight and engaging in pathogenic weight control behaviours.

375 Regarding the role of team norms, one quantitative study sampling male and female

376 athletes from a range of sports (Engel et al., 2003) identified significant positive associations

377 between athletes' EDI scores (Garner, 1991) and their perceptions of teammates' engagement 
Teammate influences on athletes' eating attitudes and behaviours

378

379

380

381

382

383

384

385

386

387

388

389

390

391

392

393

394

395

396

397

398

399

400

401

402

403

in dieting, purging and binge-eating behaviours. Similarly, regarding body shape and weight, Bloodworth et al.'s (2017) qualitative study reported that male and female aesthetic athletes also have implicit shared notions of which eating attitudes and behaviours are appropriate.

Aside from normative beliefs, two quantitative studies which sampled athletes from a range of sport types investigated the presence of perceived "pressure" from teammates to achieve or maintain a particular weight or body shape although the authors do not detail the mechanisms by which this pressure manifests. It was found that female athletes with eating disorders (as classified by the Q-EDD), or those who were symptomatic, were found to perceive higher teammate pressures compared to asymptomatic athletes (Petrie et al., 2009). Furthermore, Petrie et al. (2007) found that perception of pressure from teammates for male symptomatic athletes was positively correlated $(\mathrm{r}=0.52)$ with bulimic attitudes and behaviours (BULIT-R; Thelen, Mintz, \& Vander Wal, 1996).

(d) Competitive comparisons. Six studies (five qualitative) explored the tendency among athletes to make comparisons with their peers, particularly in relation to weight, shape and the use of weight control methods with competitive aspects to these comparisons and environmental / individual differences evident.

Arthur-Cameselle et al. (2017) found that competitive dieting among female peers was more likely to occur in athletes from a range of sports $(58 \%)$ than non-athletes $(18 \%)$, with this discrepancy attributed to the highly competitive environment athletes often train in. In line with this, male and female gymnasts $(58.3 \%)$ reported that training and competing in what they perceive to be a low competitiveness environment may protect them against developing disordered eating behaviours (Francisco et al., 2012). In contrast, the male and female dancers in this study (who reported training in an extremely competitive environment) were often found to make competitive comparisons relating to the appearance and weight of their classmates. Furthermore, in a similar aesthetic male sample, appearance comparisons were also reported; "Just looking at the other skaters, they look so good you work to be like 
Teammate influences on athletes' eating attitudes and behaviours

404 them" (Voelker et al., 2018, p.123). Likewise in a male ball-game sample, players reported

405 facing stiff competition for places on the team and, in response, felt pressured to "trim"

406 (Smart \& Bisogni, 2001, p.61) any extra pounds in order to obtain a selection advantage over

407 their teammates.

In addition, evidence from the included studies indicated that comparisons for weight,

409 shape and weight control methods were more likely to occur in female aesthetic athletes

410 already at a high risk of disordered eating attitudes and behaviours (EAT-26 score $>$ 20; Toro

411 et al., 2009), or in female athletes from a range of sports with a hyper-competitive personality

412 (Stirling \& Kerr, 2012). Indeed, hyper-competitive athletes frequently reported competing

413 with their teammates to be the thinnest and to set the most extreme weight loss goals, despite

414 being aware of the negative health consequences (Stirling \& Kerr, 2012).

\section{Discussion}

The aim was to systematically review the available literature and synthesise the

417 findings regarding the influence of teammates on athlete eating attitudes and behaviours.

418 Overall, this review found evidence to suggest that teammates can be influential in a variety

419 of ways. Teammates were found to be a positive influence via three teammate support

420 mechanisms: (1) the promotion of healthy eating practices; (2) adopting specific practices to

421 address disordered eating behaviours in fellow team members; and (3) supportive teammate

422 friendships. However, teammates were also found to be a negative influence via four

423 mechanisms of teammate pressure: (1) conflicting teammate friendships, (2) critical

424 comments and appearance conversations, (3) maladaptive team norms, and (4) competitive

425 comparisons with teammates.

426 Implicit and explicit team norms were identified as important mechanisms of

427 teammate influences on athlete eating behaviour. Higher levels of awareness of implicit team

428 norms (e.g., for healthy eating practices) were linked to lower intentions to engage in these

429 behaviours (Karpinski \& Milliner, 2016), whereas athletes identified the establishment of 
Teammate influences on athletes' eating attitudes and behaviours

430

431

432

433

434

435

436

437

438

439

440

441

442

443

444

445

446

447

explicit healthy eating norms (e.g., at pre-season team meetings) as having a positive influence on their eating practices (Kroshus et al., 2014). To date, however, no empirical studies have investigated the efficacy of establishing explicit team norms in reducing disordered eating attitudes and behaviours amongst team members or extrapolated beyond eating behaviour intentions in relation to implicit norms in athlete groups. This may be a valuable line of inquiry for future research, as cohesive and supportive sports teams may provide an ideal environment in which to initiate interventions relating to healthy eating and body satisfaction (Paxton, 1996).

In contrast, perceived maladaptive team norms towards food, weight and shape (e.g., beliefs that teammates were engaged in pathological eating behaviours) were linked to increased disordered eating attitudes and behaviours among individual team members (Engel et al., 2003). This supports previous suggestions that actual or perceived pressure from teammates can lead some athletes to believe that disordered eating attitudes and behaviours are the norm even if this is not the case (Thompson \& Sherman, 1999a, 1999b). Evidence within this review revealed that some teams were avoidant of, or lacked vigilance for, disordered eating behaviours among their teammates (Kroshus et al., 2014; Smith \& Ogle, 2006). Such reactions may serve to perpetuate disordered eating behaviours among their peers, by leaving them unchallenged and persistent within the team environment.

Nonetheless, this review also found evidence to suggest that some teammates play an active role in preventing disordered eating through the provision of anti-dieting advice and by challenging "fat talk" (Kroshus et al., 2015; Smith \& Ogle, 2006). In some studies, it was clear that athletes had a high level of awareness of potential eating issues amongst their teammates and were willing to provide support where it was perceived necessary. Older athletes demonstrated an awareness of the potential impressionability of their younger peers and reported making conscious decisions (e.g., avoid talking about their body dissatisfaction) to protect them from observing and subsequently modelling potentially pathological eating 
Teammate influences on athletes' eating attitudes and behaviours

456

457

458

459

460

461

462

463

464

465

466

467

468

469

470

471

472

473

474

475

476

477

478

479

480

attitudes (Bloodworth et al., 2017). These findings could be useful in designing and pitching future healthy eating interventions to sports teams. For example, older teammates could be trained to play the role of "fat talk challenger", and in modelling healthy eating behaviours (e.g., selecting adequate portion sizes, Smart \& Bisogni, 2001) to promote positive eating practices among teams.

The evidence regarding the influence of teammate friendships on athlete eating attitudes and behaviours was mixed. Longitudinal evidence indicated that teammate social support was associated with a reduction in disordered eating attitudes and behaviours (Shanmugam et al., 2014), while interpersonal conflict among teams was associated with higher levels of disordered eating attitudes and behaviours (Shanmugam et al., 2014). This is in line with other research indicating that poor-quality, discordant athlete teammate relationships are linked to negative outcomes such as reduced team cohesion and athletic performance (Holt \& Sparkes, 2001). However, additional research is warranted to comprehensively investigate the impact of both negative and positive dimensions of teammate relationships on eating attitudes and behaviours, before suggestions for intervention efforts can be reliably made.

Furthermore, studies included within the review provided evidence to suggest that highly competitive training environments may facilitate comparative processes among athletes (specifically for appearance, weight and/or shape), and that such comparisons were associated with increases in disordered eating behaviours (Bloodworth et al., 2017; Francisco et al., 2012; Stirling \& Kerr, 2012; Toro et al., 2009). This aligns with previous findings that have demonstrated elevated disordered eating behaviours and "competitive thinness" tendencies among athletes who report ego-involved training environments (i.e. where the emphasis is on competition) versus those who report task-focused environments (i.e. emphasis on learning and improvement; de Bruin, Bakker, \& Oudejans, 2009). 
Teammate influences on athletes' eating attitudes and behaviours

Aside from the aforementioned implicit influences (negative teammate relationships, maladaptive team norms, competitive comparisons), explicit teammate influences, such as negative verbal interactions (e.g., critical comments, weight loss and appearance-based

disordered eating in this review (e.g., Arthur-Cameselle et al., 2017; Francisco et al., 2012).

This is in line with existing longitudinal research indicating that the receipt of a critical comment from a significant other (e.g., coach) is linked to eating disorder onset (Stice, 2016).

Notably, the negative effects of these interactions may be more pronounced among younger athletes, with a higher frequency of received comments, and an increased impact of critical comments reported among this group (Francisco et al., 2012). It is important that significant others in the athletes' network, such as their senior teammates, are attune to the potential negative impact of remarks about fellow athletes' weight/shape.

Very few studies provided direct comparisons between males and females or between younger and older athletes in terms of either their susceptibility towards, or the direction of, teammate influences. Of those studies that did $(n=3)$, there was tentative evidence to suggest that females and younger / newer team members were more susceptible to negative teammate influences. This supports literature from the general population which indicates that age and gender are key factors influencing the likelihood of conformity to peer group norms (e.g., Berndt, 1979; Eagly \& Chrvala, 1986). Further work is needed to explore the potential moderating roles of gender and age in the relationship between teammate influences and eating psychopathology.

The findings of the review point towards the following recommendations for coaches and sporting organisations in order to protect athletes against the development of disordered eating attitudes and behaviours: (1) Encourage and establish positive team norms around healthy eating practices and refute or discourage maladaptive behaviours among team members (e.g., disordered eating practices); (2) Foster team cohesion and facilitate the 
Teammate influences on athletes' eating attitudes and behaviours

507 development of supportive teammate relationships that are well equipped to recognise and

508 tackle instances disordered eating; (3) Adopt a task-involved (as opposed to ego-involved) environment which may reduce competitiveness amongst teammates and help to protect against disordered eating. methodological quality. All of the articles were rated as either reasonable $(n=15)$ or good

513 quality $(n=9)$. While the majority of the studies reported in detail the measures and procedures employed and had sufficiently large sample sizes to address their research question, many were lacking sufficient detail in relation to their description of the athlete sample. Notably the competitive level of the athletes was not reported in enough detail to

517 categorise athlete competition level (Swann et al., 2015), which aligns with much of the

518 extant athlete eating behaviour literature. Furthermore, the role of competitive level in 519 disordered eating practices is also noted to be inconsistent (Hausenblas \& Carron, 1999; Holm-Denoma, Scaringi, Gordon, Van Orden \& Joiner Jr, 2009; Pritchard, Rush, \& Milligan, 2007). Consequently, it was not possible to draw any valid conclusions about the moderating influence of competition level on the relationship between teammate influences and eating behaviours. Future research in this area should take care to accurately describe athlete samples in sufficient detail to allow the role of these factors to be assessed. used by studies within this review had been validated for use in athletes, while all of the quantitative studies employed self-report measures of current disordered eating behaviours or intended healthy eating behaviours. This is a potential limitation given the tendency towards under-reporting of disordered eating practices among athlete populations (Torstveit, Rosenvinge, \& Sundgot-Borgen, 2008). Therefore, future researchers should aim to use

531 measures that have been appropriately validated with athlete samples. In addition, given the

532 wide range of measures employed to assess disordered eating attitudes and behaviours, it is 
Teammate influences on athletes' eating attitudes and behaviours

533 also plausible that any discrepancy in findings could be due to the different ways in which

534 constructs were assessed. Indeed, while all of the standardised eating measures employed by

535 included studies assessed both disordered eating attitudes and behaviours, some assessed

536 primarily eating attitudes (e.g., EAT-26; Garner et al., 1982) with a view to indicating

537 prevalence of sub-clinical disordered eating, whereas others primarily assessed eating

538 behaviours based on the DSM (e.g., Q-EDD; Mintz, O’halloran, Mulholland, \& Schneider,

539 1997) with a view to providing an ED diagnosis. This meant that it was not possible to

540 delineate between the two constructs (attitudes versus behaviours) to assess where teammate

541 influences had more of an impact, or to confidently compare findings between measures.

542 Finally, only two studies included a control group (Arthur-Cameselle et al., 2017; Toro et al.,

543 2009) which means that the majority of studies were unable to make comparative deductions

544 to ascertain whether identified influences were specific to or stronger/weaker amongst

545 athletic teams.

Regarding generalisability, athletes were primarily Caucasian, were all from western

547 countries and primarily participated individually in either endurance, aesthetic or power

548 sports or as a team in ball-game sports (as defined by Sundgot-Borgen, 1993). As a result, the

549 findings from this review may not apply to certain sport types (e.g., weight-class, Hall \&

550 Lane, 2001) and sub-populations (e.g., African-American athletes, Johnson et al., 2004;

551 Pernick et al., 2006) who may differ in their risk of disordered eating and susceptibility to

552 teammate influences. Furthermore, it is plausible to suggest that the 'contagion' of eating

553 disturbances may be more likely among team sport athletes compared to individual sports

554 which are over-represented in this review (e.g., aesthetic, endurance, power; Thompson \&

555 Sherman, 2011). Future research should look to include under-represented athletic

556 populations before firm conclusions about the mechanisms and overall valence of teammate

557 influence can be drawn.

558 This review was conducted in a reliable manner using a systematic approach and 
Teammate influences on athletes' eating attitudes and behaviours

559 adhering strictly to the transparent reporting systems of PRISMA. Furthermore, thorough risk

560 of bias assessments using guidelines (Gilbert, 2009; NICE, 2012) provided a rigorous method

561 for establishing the methodological quality of the included studies. This is the first review to

562 synthesise findings in relation to teammate influences on athlete eating attitudes and

563 behaviours, with evidence to suggest that teammates can be influential (both positively and

564 negatively) through a variety of mechanisms. In addition, this review adds to the existing

565 literature by documenting how individual factors (e.g., age, personality characteristics) and

566 environmental factors (e.g., perceived competitiveness of the training environment) may

567 affect athletes' susceptibility to teammate influences. These will be important factors to

568 consider when designing and implementing future healthy eating behaviour interventions in

569 sports teams.

\section{Conclusion}

This systematic review has highlighted that teammates can have both a positive and

negative influence on athlete eating attitudes and behaviours. In particular, positive mechanisms of influence include the promotion of healthy eating practices, vigilance against

574 the development of disordered eating, and the existence of supportive teammate friendships.

575 On the other hand, negative mechanisms of influence include conflicting teammate

576 friendships, maladaptive team norms, critical comments and appearance conversations, and

577 competitive comparisons between teammates. These findings will help to inform the

578 development of future interventions to facilitate healthy eating behaviours and healthy weight

579 in athletes. Further research is needed to allow more definitive conclusions to be drawn about

580 the circumstances under which teammates influence athlete eating attitudes and behaviours. 
Teammate influences on athletes' eating attitudes and behaviours

References

582

583

584

585

586

587

588

589

590

591

592

593

594

595

596

597

598

599

600

601

602

603

604

605

606

607

608

609

610

611

612

613

614

615

616

617

618

619

620

621

622

623

624

Araújo, C. G. S., \& Scharhag, J. (2016). Athlete: a working definition for medical and health sciences research. Scandinavian Journal of Medicine \& Science in Sports, 26(1), 4-7.

Arthur-Cameselle, J. N., \& Quatromoni, P. A. (2011). Factors related to the onset of eating disorders reported by female collegiate athletes. The Sport Psychologist, 25(1), 1-17.

Arthur-Cameselle, J., Sossin, K., \& Quatromoni, P. (2017). A qualitative analysis of factors related to eating disorder onset in female collegiate athletes and non-athletes. Eating Disorders, 25(3), 199-215.

Berndt, T. J. (1979). Developmental changes in conformity to peers and parents. Developmental Psychology, 15(6), 608.

Bloodworth, A., McNamee, M., \& Tan, J. (2017). Autonomy, eating disorders and elite gymnastics: ethical and conceptual issues. Sport, Education and Society, 22(8), 878889.

Bryne, S., \& McLean, N. (2002). Elite athletes: effects of the pressure to be thin. Journal of Science \& Medicine in Sport, 5(2), 80-94.

Cruwys, T., Bevelander, K. E., \& Hermans, R. C. J. (2015). Social modeling of eating: A review of when and why social influence affects food intake and choice. Appetite, 86, $3-$ 18.

Darcy, A. M., Hardy, K. K., Crosby, R. D., Lock, J., \& Peebles, R. (2013). Factor structure of the Eating Disorder Examination Questionnaire (EDE-Q) in male and female college athletes. Body Image, 10(3), 399-405.

de Bruin, K., Bakker, F., \& Oudejans, R. (2009). Achievement goal theory and disordered eating: Relationships of disordered eating with goal orientations and motivational climate in female gymnasts and dancers. Psychology of Sport and Exercise, 10(1), 7279.

Doninger, G. L., Enders, C. K., \& Burnett, K. F. (2005). Validity evidence for Eating Attitudes Test scores in a sample of female college athletes. Measurement in Physical Education and Exercise Science, 9(1), 35-49.

Eagly, A. H., \& Chrvala, C. (1986). Sex differences in conformity: Status and gender role interpretations. Psychology of Women Quarterly, 10(3), 203-220.

Engel, S. G., Johnson, C., Powers, P. S., Crosby, R. D., Wonderlich, S. A., Wittrock, D. A., $\&$ Mitchell, J. E. (2003). Predictors of disordered eating in a sample of elite Division I college athletes. Eating Behaviors, 4(4), 333-343.

Fairburn, C., \& Beglin, S. (2008). Eating Disorder Examination. In C. Fairburn (Ed.), Cognitive Behavior Therapy and Eating Disorders (pp. 265-355). New York, NY: Guildford Press.

Fairburn, C. G., Cooper, Z., Shafran, R., \& Wilson, G. T. (2008). Eating disorders: A transdiagnostic protocol. In H. Barlow, D (Ed.), Clinical handbook of psychological disorders: A step-by-step treatment manual (pp. 578-614). New York, NY, US: Guildford Press.

Franchini, E., Brito, C., \& Artioli, G. (2012). Weight loss in combat sports: physiological, psychological and performance effects. Journal of the International Society of Sports Nutrition, 9(1), 52.

Francisco, R., Alarcão, M., \& Narciso, I. (2012). Aesthetic sports as high-risk contexts for 
eating disorders - Young elite dancers and gymnasts perspectives. The Spanish Journal of Psychology, 15(1), 265-274.

Friedlander, L. J., Reid, G. J., Shupak, N., \& Cribbie, R. (2007). Social support, self-esteem, and stress as predictors of adjustment to university among first-year undergraduates. Journal of College Student Development, 48(3), 259-274.

Galli, N., Petrie, T., \& Chatterton, J. (2017). Team weigh-ins and self-weighing: Relations to body-related perceptions and disordered eating in collegiate male athletes. Psychology of Sport and Exercise, 29, 51-55.

Galli, N., \& Reel, J. J. (2009). Adonis or Hephaestus? Exploring body image in male athletes. Psychology of Men \& Masculinity, 10(2), 95-108.

Garner, D. M. (1991). Eating disorder inventory-2. Professional manual. Odessa, FL: Psychological Assessment Resources.

Garner, D. M., Olmsted, M. P., Bohr, Y., \& Garfinkel, P. E. (1982). The eating attitudes test: psychometric features and clinical correlates. Psychological Medicine, 12(4), 871-878.

Gilbert, N. (2009).Disclosure of eating disorders and subsequent help seeking. Doctoral dissertation. University of Birmingham. http://etheses.bham.ac.uk/428/. Accessed 10 Jan 2018.

Hall, C. J., \& Lane, A. M. (2001). Effects of rapid weight loss on mood and performance among amateur boxers. British Journal of Sports Medicine, 35(6), 390-395.

Hausenblas, H. A., \& Carron, A. V. (1999). Eating disorder indices and athletes: An integration. Journal of Sport and Exercise Psychology, 21(3), 230-258.

Herman, C. P. (2015). The social facilitation of eating. A review. Appetite, 86, 61-73.

Herman, C. P., \& Higgs, S. (2015). Social influences on eating. An introduction to the special issue. Appetite, 86(0), 1-2.

Higgs, S. (2015). Social norms and their influence on eating behaviours. Appetite, 86, 38-44. Hinton, P. S., \& Kubas, K. L. (2005). Psychosocial correlates of disordered eating in female collegiate athletes: validation of the ATHLETE questionnaire. Journal of American College Health, 54(3), 149-156.

Holm-Denoma, J. M., Scaringi, V., Gordon, K, H., Van Orden, K, A., \& Joiner Jr, T, E. (2009). Eating disorder symptoms among undergraduate varisty athletes, club athletes, independent exercises, and nonexercisers. International Journal of Eating Disorders, $42(1), 47-53$.

Holt, N. L., \& Sparkes, A. C. (2001). An ethnographic study of cohesiveness in a college soccer team over a season. The Sport Psychologist, 15(3), 237-259.

Johnson, C., Crosby, R., Engel, S., Mitchell, J., Powers, P., Wittrock, D., \& Wonderlich, S. (2004). Gender, ethnicity, self-esteem and disordered eating among college athletes. Eating Behaviors, 5(2), 147-156.

Jowett, S. (2009). Validating coach-athlete relationship measures with the nomological network. Measurement in Physical Education and Exercise Science, 13(1), 34-51.

Karpinski, C. A., \& Milliner, K. (2016). Assessing Intentions to Eat a Healthful Diet Among National Collegiate Athletic Association Division II Collegiate Athletes. Journal of Athletic Training (Allen Press), 51(1), 89-96.

Kroshus, E., Goldman, R. E., Kubzansky, L. D., \& Austin, S. B. (2014). Team-level approaches to addressing disordered eating: A qualitative study of two female collegiate cross country running teams. Eating Disorders, 22(2), 136-151. 
Kroshus, E., Kubzansky, L., Goldman, R., \& Austin, S. B. (2015). Anti-dieting advice from teammates: a pilot study of the experience of female collegiate cross country runners. Eating Disorders, 23(1), 31-44.

Martinsen, M., Bratland-Sanda, S., Eriksson, A., \& Sundgot-Borgen, J. (2010). Dieting to win or be thin? A study of dieting and disordered eating among adolescent elite athletes and non-athlete controls. British Journal of Sports Medicine, 44(1), 70-76.

McCabe, M., \& Ricciardelli, L. (2001). Parent, peer and media influences on body image ansd strategies to both increase and decrease body size among adolescent boys and girls. Adolescence, 36(142), 225-240.

Mintz, L. B., O’halloran, M. S., Mulholland, A. M., \& Schneider, P. A. (1997). Questionnaire for Eating Disorder Diagnoses: Reliability and validity of operationalizing DSM-IV criteria into a self-report format. Journal of Counseling Psychology, 44(1), 63.

Moher, D., Liberati, A., Tetzlaff, J., Altman, D. G., \& Group, P. (2010). Preferred reporting items for systematic reviews and meta-analyses: the PRISMA statement. International Journal of Surgery, 8(5), 336-341.

Muscat, A. C., \& Long, B. C. (2008). Critical comments about body shape and weight: Disordered eating of female athletes and sport participants. Journal of Applied Sport Psychology, 20(1), 1-24.

Nattiv, A., Loucks, A. B., Manore, M. M., Sanborn, C. F., Sundgot-Borgen, J., \& Warren, M. P. (2007). The female athlete triad special communications: position stand. Med Sci Sports Exerc, 39(10), 1867-1882.

Neumark-Sztainer, D., Story, M., \& Casey, M. (1999). Factors influencing food choices of adolescents: Findings from focus-group discussions with adolescents. Journal of the American Dietetic Association, 99(8), 929-937.

NICE. (2012). The guidelines manual. London: National Institute for Health and Care Excellence. Retrieved from https://www.nice.org.uk/process/pmg6/chapter/reviewingthe-evidence

Pawlak, R., Malinauskas, B., \& Rivera, D. (2009). Predicting intentions to eat a healthful diet by college baseball players: applying the theory of planned behavior. Journal of Nutrition Education and Behavior, 41(5), 334-339.

Paxton, S. J. (1996). Prevention implications of peer influences on body image dissatisfaction and disturbed eating in adolescent girls. Eating Disorders, 4(4), 334-347.

Pernick, Y., Nichols, J. F., Rauh, M. J., Kern, M., Ji, M., Lawson, M., \& Wilfley, D. (2006). Disordered eating among a multi-racial/ethnic sample of female high-school athletes. Journal of Adolescent Healthm, 38(6), 689-695.

Petrie, T. A., Greenleaf, C., Carter, J. E., \& Reel, J. J. (2007). Psychosocial correlates of disordered eating among male collegiate athletes. Journal of Clinical Sport Psychology, $1(4), 340-357$.

Petrie, T. A., Greenleaf, C., Reel, J., \& Carter, J. (2008). Prevalence of eating disorders and disordered eating behaviours among male collegiate athletes. Psychology of Men \& Masculinity, 9(4), 267.

Petrie, T. A., Greenleaf, C., Reel, J. J., \& Carter, J. E. (2009). An Examination of Psychosocial Correlates of Eating Disorders Among Female Collegiate Athletes. Research Quarterly for Exercise \& Sport, 80(3), 621-632.

Polivy, J., \& Pliner, P. (2015). "She got more than me". Social comparison and the social 

context of eating. Appetite, 86, 88-95.

Pritchard, M., Rush, P., \& Milligan, B. (2007). Risk factors for disordered eating in high school and college athletes. Athlet Insight Online J Sport Psychol, 9(3).

Reel, J., \& Gill, D. L. (1996). Psychosocial factors related to eating disorders among high school and college female cheerleaders. The Sport Psychologist, 10(2), 195-206.

Ridgeway, R., \& Tylka, T. (2005). College Men's Perceptions of Ideal Body Composition and Shape. Psychology of Men \& Masculinity, 6(3), 209.

Scoffier, S., Maïano, C., \& d'Arripe-Longueville, F. (2010). The effects of social relationships and acceptance on disturbed eating attitudes in elite adolescent female athletes: The mediating role of physical self-perceptions. International Journal of Eating Disorders, 43(1), 65-71.

Scoffier, S., Woodman, T., \& d'Arripe-Longueville, F. (2011). Psychosocial consequences of disordered eating attitudes in elite female figure skaters. European Eating Disorders Review, 19(3), 280-287.

Shanmugam, V., Jowett, S., \& Meyer, C. (2013). Eating psychopathology amongst athletes: The importance of relationships with parents, coaches and teammates. International Journal of Sport and Exercise Psychology, 11(1), 24-38.

Shanmugam, V., Jowett, S., \& Meyer, C. (2014). Interpersonal difficulties as a risk factor for athletes' eating psychopathology. Scandinavian Journal of Medicine \& Science in Sports, 24(2), 469-476.

Smart, L. R., \& Bisogni, C. A. (2001). Personal food systems of male college hockey players. Appetite, 37(1), 57-70.

Smith, A. L. (2007). Youth peer relationships in sport. In Social psychology in sport (pp. 4154). Champaign, IL: Human Kinetics.

Smith, P., \& Ogle, J. (2006). Interactions Among High School Cross-Country Runners and Coaches: Creating a Cultural Context for Athletes' Embodied Experiences. Family and Consumer Sciences Research Journal, 34(3), 276-307.

Smolak, L., \& Chun-Kennedy, C. (2015). Sociocultural influences on the development of eating disorders and obesity. In Eating disorders and obesity: A counselor's guide to prevention and treatment (pp. 1-20).

Stice, E. (1998). Modeling of eating pathology and social reinforcement of the thin-ideal predict onset of bulimic symptoms. Behaviour Research and Therapy, 36(10), 931-944.

Stice, E. (2016). Interactive and mediational etiologic models of eating disorder onset: Evidence from prospective studies. Annual Review of Clinical Psychology, 12, 359-381.

Stickler, L., Armstrong, T., Polso, A., \& Smith, M. (2016). Perspectives of Female Collegiate Cross Country Runners on Eating Behaviors and Attitudes Toward Health: A Qualitative Study. Women in Sport \& Physical Activity Journal, 24(2), 81-90.

Stirling, A., \& Kerr, G. (2012). Perceived vulnerabilities of female athletes to the development of disordered eating behaviours. European Journal of Sport Science, 12(3), $262-273$.

Stoeber, J., Madigan, D., Damian, L., Esposito, R., \& Lombardo, C. (2017). Perfectionism and eating disorder symptoms in female university students: the central role or perfectionistic self-presentation. Eating and Weight Disorders-Studies on Anorexia, Bulimia and Obesity, 22(4), 641-648.

Sun, Y, H, C. (2008). Health concern, food choice motives, and attitudes toward healthy 
eating: the mediating role of food choice motives. Appetite, 51(1), 42-49.

Sundgot-Borgen, J. (1993a). Nutrient intake of female elite athletes suffering from eating disorders. / Apports alimentaires chez des athletes feminines d'elite souffrant de troubles nutritionnels. International Journal of Sport Nutrition, 3(4), 431-442.

Sundgot-Borgen, J. (1993b). Prevalence of eating disorders in elite female athletes. International Journal of Sport Nutrition, 3(1), 29-40.

Sundgot-Borgen, J. (1994). Eating disorders in female athletes. Sports Medicine, 17(2), 176188.

Sundgot-Borgen, J., \& Torstveit, M. K. (2004). Prevalence of eating disorders in elite athletes is higher than in the general population. Clinical Journal of Sport Medicine, 14(1), 2532. Retrieved from http://articles.sirc.ca/search.cfm?id=S-922972 expert performance in sport psychology. Psychology of Sport and Exercise, 16, 3-14.

Thelen, M. H., Mintz, L. B., \& Vander Wal, J. S. (1996). The Bulimia Test-Revised: Validation with DSM-IV criteria for bulimia nervosa. Psychological Assessment, 8(2), 219.

Thompson, J. K., Shroff, H., Herbozo, S., Cafri, G., Rodriguez, J., \& Rodriguez, M. (2006). Relations among multiple peer influences, body dissatisfaction, eating disturbance, and self-esteem: A comparison of average weight, at risk of overweight, and overweight adolescent girls. Journal of Pediatric Psychology, 32(1), 24-29.

Thompson, R. A., \& Sherman, R. T. (1999a). Athletes, athletic performance, and eating disorders: Healthier alternatives. Journal of Social Issues, 55(2), 317-337.

Thompson, R. A., \& Sherman, R. T. (1999b). "Good athlete” traits and characteristics of anorexia nervosa: Are they similar? Eating Disorders, 7(3), 181-190.

Thompson, R. A., \& Sherman, R. T. (2011). Eating disorders in sport. Routledge.

Toro, J., Guerrero, M., Sentis, J., Castro, J., \& Puertolas, C. (2009). Eating disorders in ballet dancing students: Problems and risk factors. European Eating Disorders Review, 17(1), $40-49$.

Torstveit, M. K., Rosenvinge, J. H., \& Sundgot-Borgen, J. (2008). Prevalence of eating disorders and the predictive power of risk models in female elite athletes: a controlled study. Scandinavian Journal of Medicine \& Science in Sports, 18(1), 108-118.

Vartanian, L. R. (2015). Impression management and food intake. Current directions in research. Appetite, 86, 74-80.

Voelker, D. K., Petrie, T. A., Reel, J. J., \& Gould, D. (2018). Frequency and Psychosocial Correlates of Eating Disorder Symptomatology in Male Figure Skaters. Journal of Applied Sport Psychology, 30(1), 119-126.

Weiss, M. R., \& Smith, A. L. (1999). Quality of youth sport friendships: Measurement development and validation. Journal of Sport and Exercise Psychology, 21(2), 145-166.

Weiss, M. R., Smith, A. L., \& Theeboom, M. (1996). “That's what friends are for": Children's and teenagers' perceptions of peer relationships in the sport domain. Journal of Sport and Exercise Psychology, 18(4), 347-379.

Wylleman, P., \& Lavallee, D. (2004). A Developmental Perspective on Transitions Faced by Athletes. In M. Weiss (Eds.), Developmental sport and exercise psychology: A lifespan perspective (pp. 507-527). Morgantown, West Virginia: Fitness Information Technologies. 
Teammate influences on athletes' eating attitudes and behaviours

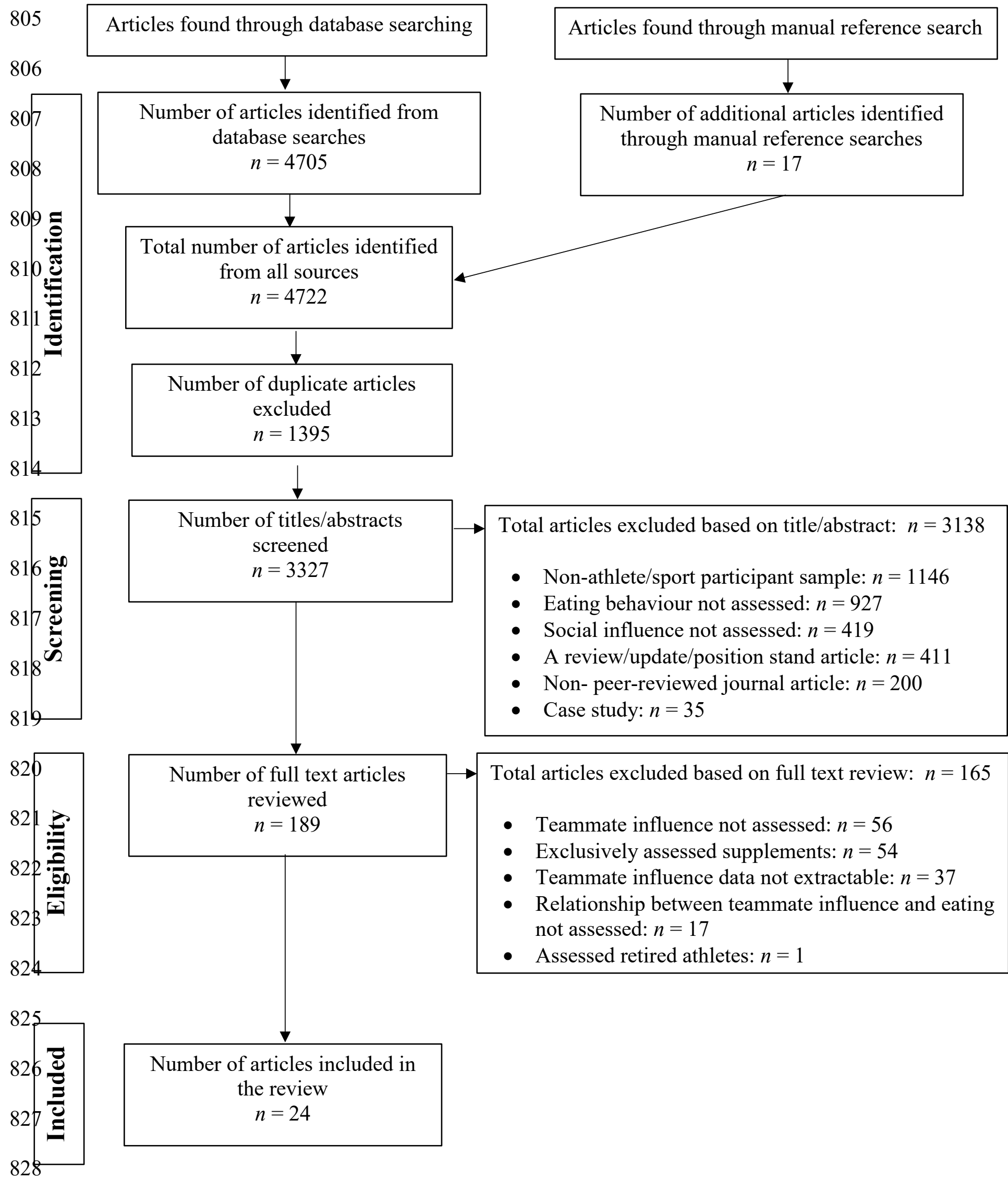

830 Figure 1.A PRISMA flowchart to show the article selection process 
Teammate influences on athletes' eating attitudes and behaviours

Table 1. Characteristics of the quantitative studies included within the review $(n=13)$

\begin{tabular}{|c|c|c|c|c|c|c|c|c|c|c|c|}
\hline Author & Year & Country & Mean age & $\begin{array}{l}\mathbf{N} \\
(\mathbf{M} / \mathbf{F})\end{array}$ & $\begin{array}{l}\text { Study } \\
\text { design }\end{array}$ & $\begin{array}{l}\text { Sport } \\
\text { category }\end{array}$ & $\begin{array}{l}\text { Time in } \\
\text { sport }\end{array}$ & $\begin{array}{l}\text { Competition } \\
\text { level }\end{array}$ & $\begin{array}{l}\text { Relevant } \\
\text { measures }\end{array}$ & Key findings & $\begin{array}{l}\text { NICE } \\
\text { rating }\end{array}$ \\
\hline Engel et al. & 2003 & America & $\begin{array}{l}\text { 19.97 years } \\
\text { (SD: } 1.68) \\
\text { Range: NR }\end{array}$ & $\begin{array}{l}562(\mathrm{~F}) \\
883(\mathrm{M})\end{array}$ & $\begin{array}{l}\text { Cross- } \\
\text { sectional }\end{array}$ & $\begin{array}{l}\text { Ball game } \\
\text { Power } \\
\text { Endurance } \\
\text { Aesthetic } \\
\text { Weight- } \\
\text { class }\end{array}$ & NR & University & $\begin{array}{l}\text { EDI-2 (DT); } \\
\text { EDI-2 (BD); } \\
\text { Restriction } \\
\text { index; Purge } \\
\text { index; Binge } \\
\text { index; } \\
\text { Perception of } \\
\text { teammate } \\
\text { variables. }\end{array}$ & $\begin{array}{l}\text { Perceptions that teammates engaged in } \\
\text { excessive dieting significantly predicted } \\
\text { higher drive for thinness, body } \\
\text { dissatisfaction, and restriction }(\beta=\geq 0.02) \text {. } \\
\text { Perceptions that teammates had purging } \\
\text { symptoms significantly predicted purging } \\
\text { and binging ( } \beta=\geq 0.02) \text {. Perceptions that } \\
\text { teammates had binging symptoms } \\
\text { significantly predicted drive for thinness } \\
(\beta=0.01) \text {. }\end{array}$ & ++ \\
\hline $\begin{array}{l}\text { Hinton \& } \\
\text { Kubas }\end{array}$ & 2005 & America & $\begin{array}{l}\text { 18-22 years } \\
\text { (SD:NR) } \\
\text { Range: NR }\end{array}$ & $167(\mathrm{~F})$ & $\begin{array}{l}\text { Cross- } \\
\text { sectional }\end{array}$ & $\begin{array}{l}\text { Ball game } \\
\text { Endurance } \\
\text { Power } \\
\text { Aesthetic }\end{array}$ & NR & University & $\begin{array}{l}\text { ATHLETE } \\
\text { Q-EDD }\end{array}$ & $\begin{array}{l}\text { Higher levels of teammate distrust } \\
\text { significantly predicted Q-EDD } \\
\text { classification } \mathrm{OR}=1.6 ; 95 \% \mathrm{CI}=1.0,2.7 \text {; } \\
\mathrm{AROC}=0.61\end{array}$ & + \\
\hline $\begin{array}{l}\text { Karpinski \& } \\
\text { Milliner }\end{array}$ & 2016 & America & $\begin{array}{l}20 \text { years } \\
(\mathrm{SD}: 1.31) \\
\text { Range: } 18-24\end{array}$ & $\begin{array}{l}43(\mathrm{M}) \\
158(\mathrm{~F})\end{array}$ & $\begin{array}{l}\text { Cross- } \\
\text { sectional }\end{array}$ & $\begin{array}{l}\text { Ball game } \\
\text { Aesthetic } \\
\text { Endurance } \\
\text { Power } \\
\text { Technical }\end{array}$ & NR & University & STPB & $\begin{array}{l}\text { The normative belief, "my teammates } \\
\text { think that I should eat a healthy diet" } \\
\text { significantly predicted less of a } \\
\text { behavioural intention to eat a healthy diet } \\
\beta=-0.29 \text {. }\end{array}$ & ++ \\
\hline $\begin{array}{l}\text { Kroshus et } \\
\text { al. }\end{array}$ & 2015 & America & $\begin{array}{l}\text { 19.76 years } \\
\text { (SD: } 1.31) \\
\text { Range: NR }\end{array}$ & $89(\mathrm{~F})$ & $\begin{array}{l}\text { Cross- } \\
\text { sectional }\end{array}$ & Endurance & NR & University & $\begin{array}{l}\text { EAT-26 } \\
\text { ADA } \\
\text { BMI }\end{array}$ & $\begin{array}{l}\text { Significant differences were found } \\
\text { between running teams in their mean level } \\
\text { of anti-dieting advice received. Higher } \\
\text { levels of disordered eating }(\beta=.09) \text { and a } \\
\text { lower BMI }(\beta=-.63) \text { significantly predicted } \\
\text { greater receipt of anti-dieting advice from } \\
\text { teammates. }\end{array}$ & ++ \\
\hline Pawlak et al. & 2009 & America & $\begin{array}{l}20.25 \text { years } \\
(\mathrm{SD}: 1.12) \\
\text { Range: } 18-24\end{array}$ & $108(\mathrm{M})$ & $\begin{array}{l}\text { Cross- } \\
\text { sectional }\end{array}$ & Ball game & NR & University & STPB & $\begin{array}{l}\text { The normative belief; "My teammates } \\
\text { think I should eat a healthful diet" did not } \\
\text { significantly correlate with or predict the } \\
\text { behavioural intention to eat a healthy diet. }\end{array}$ & + \\
\hline
\end{tabular}


Teammate influences on athletes' eating attitudes and behaviours

Table 1. Continued

\begin{tabular}{|c|c|c|c|c|c|c|c|c|c|c|c|}
\hline Author & Year & Country & Mean age & $\begin{array}{l}\mathbf{N} \\
(\mathbf{M} / \mathbf{F})\end{array}$ & $\begin{array}{l}\text { Study } \\
\text { design }\end{array}$ & $\begin{array}{l}\text { Sport } \\
\text { category }\end{array}$ & $\begin{array}{l}\text { Time in } \\
\text { sport }\end{array}$ & $\begin{array}{l}\text { Competition } \\
\text { level }\end{array}$ & $\begin{array}{l}\text { Relevant } \\
\text { measures }\end{array}$ & Key findings & $\begin{array}{l}\text { NICE } \\
\text { rating }\end{array}$ \\
\hline Petrie et al. & 2007 & America & $\begin{array}{l}20.30 \text { years } \\
\text { (SD: } 1.73 \text { ) } \\
\text { Range: NR }\end{array}$ & $199(\mathrm{M})$ & $\begin{array}{l}\text { Cross- } \\
\text { sectional }\end{array}$ & $\begin{array}{l}\text { Ball game } \\
\text { Aesthetic } \\
\text { Endurance } \\
\text { Technical } \\
\text { Power }\end{array}$ & $\begin{array}{l}\text { Mean: } 8.70 \\
\text { years } \\
\text { (SD:5.28) }\end{array}$ & University & $\begin{array}{l}\text { Q-EDD } \\
\text { WPS; } \\
\text { DMS } \\
\text { BPSS-R-Body } \\
\text { Body } \\
\text { satisfaction in } \\
\text { last } 3 \text { months } \\
\text { Bulit-R } \\
\text { MBSRQAET- } \\
\text { AE }\end{array}$ & $\begin{array}{l}\text { Symptomatic athletes: pressure from } \\
\text { teammates significantly correlated with } \\
\text { bulimia symptoms }(r=0.52) \text { and drive for } \\
\text { muscularity ( } r=0.45) \text { but not body } \\
\text { satisfaction in the last } 3 \text { months, body- } \\
\text { self relations or body parts satisfaction. } \\
\text { Asymptomatic athletes: pressure from } \\
\text { teammates significantly correlated with } \\
\text { drive for muscularity ( } r=0.44) \text {, body } \\
\text { satisfaction in the last } 3 \text { months }(r=-0.37) \\
\text { and body parts satisfaction }(r=-0.46) \text { but } \\
\text { not with bulimia symptoms or body-self } \\
\text { relations. }\end{array}$ & ++ \\
\hline Petrie et al. & 2009 & America & $\begin{array}{l}19.68 \text { years } \\
\text { (SD: } 1.33 \text { ) } \\
\text { Range: NR }\end{array}$ & $442(\mathrm{~F})$ & $\begin{array}{l}\text { Cross- } \\
\text { sectional }\end{array}$ & $\begin{array}{l}\text { Ball game } \\
\text { Aesthetic } \\
\text { Endurance } \\
\text { Power } \\
\text { Technical }\end{array}$ & $\begin{array}{l}\text { Mean: } 8.89 \\
\text { years } \\
(\mathrm{SD}: 4.80)\end{array}$ & University & $\begin{array}{l}\text { Q-EDD } \\
\text { WPS }\end{array}$ & $\begin{array}{l}\text { Athletes with eating disorders and those } \\
\text { that were symptomatic reported } \\
\text { receiving more pressure from teammates } \\
(d=0.63) \text { compared to the asymptomatic } \\
\text { group }(d=0.36) .\end{array}$ & ++ \\
\hline $\begin{array}{l}\text { Scoffier et } \\
\text { al. }\end{array}$ & 2010 & France & $\begin{array}{l}15.75 \text { years } \\
\text { (SD:3.00) } \\
\text { Range: NR }\end{array}$ & $227(\mathrm{~F})$ & $\begin{array}{l}\text { Cross- } \\
\text { sectional }\end{array}$ & Aesthetic & $\begin{array}{l}\text { Mean: } 8.78 \\
\text { years } \\
(\mathrm{SD}: 1.12)\end{array}$ & $\begin{array}{l}\text { National } \\
\text { International }\end{array}$ & $\begin{array}{l}\text { SFQS } \\
\text { EAT-26 } \\
\text { SDQ-11-PPA }\end{array}$ & $\begin{array}{l}\text { Sport friendship quality positively } \\
\text { predicted disordered eating scores } \\
\text { through the mediating role of perceived } \\
\text { physical ability }(\beta=0.24)\end{array}$ & + \\
\hline $\begin{array}{l}\text { Scoffier et } \\
\text { al. }\end{array}$ & 2011 & France & $\begin{array}{l}14.35 \text { years } \\
(\mathrm{SD}: 2.80) \\
\text { Range: } 11-18\end{array}$ & $199(\mathrm{~F})$ & $\begin{array}{l}\text { Cross- } \\
\text { sectional }\end{array}$ & Aesthetic & $\begin{array}{l}\text { Mean: } 7.55 \\
\text { years } \\
(\mathrm{SD}: 1.40)\end{array}$ & National & $\begin{array}{l}\text { EAT-26 } \\
\text { SFQS }\end{array}$ & $\begin{array}{l}\text { Sport friendship quality was not } \\
\text { significantly correlated with disordered } \\
\text { eating scores. }\end{array}$ & + \\
\hline $\begin{array}{l}\text { Shanmugam } \\
\text { et al. }\end{array}$ & 2014 & UK & $\begin{array}{l}21.22 \text { years } \\
(\mathrm{SD}: 4.01) \\
\text { Range: } 17-35\end{array}$ & $\begin{array}{l}86(\mathrm{~F}) \\
36(\mathrm{M})\end{array}$ & Prospective & $\begin{array}{l}\mathrm{NR}(62 \% \\
\text { individual } \\
\text { sports })\end{array}$ & $\begin{array}{l}\text { Mean: } 7.73 \\
\text { years } \\
\text { (SD:4.99) }\end{array}$ & $\begin{array}{l}\text { Mixed } \\
\text { competitive } \\
\text { levels }\end{array}$ & $\begin{array}{l}\text { EDE-Q } \\
\text { SSQRI- social } \\
\text { support } \\
\text { SSQRI- } \\
\text { interpersonal } \\
\text { conflict }\end{array}$ & $\begin{array}{l}\text { Teammate social support at T1 was } \\
\text { negatively correlated with global } \\
\text { disordered eating scores at T2 }(r=-0.17) \text {. } \\
\text { Teammate conflict at T1 was positively } \\
\text { correlated with global disordered eating } \\
\text { scores at T2 }(r=0.19) \text {. }\end{array}$ & ++ \\
\hline
\end{tabular}


Table 1. Continued

\begin{tabular}{|c|c|c|c|c|c|c|c|c|c|c|c|}
\hline Author & Year & Country & Mean age & $\mathbf{N}(\mathbf{M} / \mathbf{F})$ & $\begin{array}{l}\text { Study } \\
\text { design }\end{array}$ & $\begin{array}{l}\text { Sport } \\
\text { category }\end{array}$ & $\begin{array}{l}\text { Time in } \\
\text { sport }\end{array}$ & $\begin{array}{l}\text { Competition } \\
\text { level }\end{array}$ & $\begin{array}{l}\text { Relevant } \\
\text { measures }\end{array}$ & Key findings & $\begin{array}{l}\text { NICE } \\
\text { rating }\end{array}$ \\
\hline $\begin{array}{l}\text { Shanmugam } \\
\text { et al. }\end{array}$ & 2013 & UK & $\begin{array}{l}20.95 \text { years } \\
\text { (SD:3.67) } \\
\text { Range: } 16-36\end{array}$ & $\begin{array}{l}252(\mathrm{~F}) \\
159(\mathrm{M})\end{array}$ & $\begin{array}{l}\text { Cross- } \\
\text { sectional }\end{array}$ & $\begin{array}{l}\text { NR }(53 \% \\
\text { individual } \\
\text { sports })\end{array}$ & $\begin{array}{l}\text { Mean:8.66 } \\
\text { years } \\
(\mathrm{SD}: 5.15)\end{array}$ & $\begin{array}{l}\text { Mixed } \\
\text { competitive } \\
\text { levels }\end{array}$ & $\begin{array}{l}\text { EDE-Q } \\
\text { SSQRI- } \\
\text { social support } \\
\text { SSQRI- } \\
\text { interpersonal } \\
\text { conflict }\end{array}$ & $\begin{array}{l}\text { Social support from teammates and } \\
\text { interpersonal conflict with teammates did } \\
\text { not significantly correlate with global } \\
\text { disordered eating scores. }\end{array}$ & ++ \\
\hline Toro et al. & 2009 & Spain & $\begin{array}{l}14.42 \text { years } \\
(\mathrm{SD}: 1.40) \\
\text { Range: } 12-17\end{array}$ & $\begin{array}{l}105(\mathrm{~F}) \\
\text { Athletes } \\
453(\mathrm{~F}) \\
\text { Controls }\end{array}$ & $\begin{array}{l}\text { Cross- } \\
\text { sectional }\end{array}$ & Aesthetic & NR & $\begin{array}{l}\text { Intermediate } \\
\text { level dance }\end{array}$ & $\begin{array}{l}\text { EAT-26 } \\
\text { Researcher } \\
\text { designed }\end{array}$ & $\begin{array}{l}\text { Those with higher disordered eating } \\
\text { scores were more likely than those with } \\
\text { lower disordered eating scores to } \\
\text { compare their bodies to their classmates } \\
(33 \% \text { vs } 15 \%, p<0.001) \text { ) and to feel } \\
\text { upset when making these comparisons } \\
(47 \% \text { vs } 12 \%, p<0.001) \text {. }\end{array}$ & ++ \\
\hline $\begin{array}{l}\text { Wadas \& } \\
\text { DeBeliso }\end{array}$ & 2014 & America & $\begin{array}{l}15.90 \text { years } \\
(\mathrm{SD}: 1.00) \\
\text { Range: } 14-18 \\
\end{array}$ & $68(\mathrm{M})$ & $\begin{array}{l}\text { Cross- } \\
\text { sectional }\end{array}$ & Endurance & NR & High school & $\begin{array}{l}\text { EAT-26 } \\
\text { ATHLETE }\end{array}$ & $\begin{array}{l}\text { No significant relationship identified } \\
\text { between support from teammates and } \\
\text { disordered eating scores. }\end{array}$ & ++ \\
\hline
\end{tabular}

Note. $\mathrm{M}=$ Male, $\mathrm{F}=$ Female, $\mathrm{NR}=$ Not Reported; EDI- DT = Eating Disorder Inventory - Drive for Thinness; EDI-BD = Eating Disorder Inventory - Body Dissatisfaction; Q-EDD= Questionnaire for Eating Disorder Diagnosis; STPB = Survey of the Theory of Planned Behaviour; EAT-26= Eating Attitudes Test (26 item); ADA= Anti-Dieting Advice Scale; BMI= Body Mass Index; WPS= Weight Pressures Scale; DMS= Drive for Muscularity Scale, BPSS-R= Body Parts Satisfaction Scale-Revised, Bulit-R= Bulimia Test Revised, MBSRQAET-AE = Multidimensional Body-Self Relations Questionnaire, Appearance Evaluation subscale; SFQS= Sport Friendship Quality Scale; SDQ-11-PPA= SelfDescription Questionnaire, Perceived Physical Ability subscale; EDE-Q = Eating Disorder Examination Questionnaire; SSQRI = Sport Specific Quality of Relationship Inventory; “-” = poor quality, “+” = reasonable quality, “++” = good quality. 
Teammate influences on athletes' eating attitudes and behaviours

Table 2. Characteristics of the qualitative studies included within the review $(n=11)$

\begin{tabular}{|c|c|c|c|c|c|c|c|c|c|c|c|}
\hline Author & Year & Country & Mean Age & $\begin{array}{c}\mathbf{N} \\
(\mathbf{M} / \mathbf{F})\end{array}$ & $\begin{array}{l}\text { Sport } \\
\text { Category }\end{array}$ & $\begin{array}{l}\text { Time in } \\
\text { sport }\end{array}$ & $\begin{array}{l}\text { Competition } \\
\text { level }\end{array}$ & Method & Key theme & Key Findings & $\begin{array}{l}\text { NICE } \\
\text { rating }\end{array}$ \\
\hline $\begin{array}{l}\text { Arthur- } \\
\text { Camesselle } \\
\text { et al. }\end{array}$ & 2017 & America & $\begin{array}{l}20.50 \text { years } \\
\text { (SD: NR) } \\
\text { Range: } 18-24\end{array}$ & $12(\mathrm{~F})$ & $\begin{array}{l}\text { Endurance } \\
\text { Power } \\
\text { Ball game }\end{array}$ & NR & University & $\begin{array}{l}\text { Semi- } \\
\text { structured } \\
\text { interview. }\end{array}$ & "Peer issues" & $\begin{array}{l}\text { Peer issues a key factor in the onset } \\
\text { of an eating disorder for } 75 \% \text { of } \\
\text { athletes. } \\
\text { Issues included "bullying/fitting in" } \\
(8 \%) \text {, "peer negative comments" } \\
(8 \%) \text {, "peer modelling of Eating } \\
\text { Disorder" }(58 \%) \text { and "romantic } \\
\text { conflicts" }(25 \%) \text {. }\end{array}$ & ++ \\
\hline $\begin{array}{l}\text { Bloodworth } \\
\text { et al. }\end{array}$ & 2017 & UK & $\begin{array}{l}17.40 \text { years } \\
\text { (SD: NR) } \\
\text { Range: } 12-21\end{array}$ & $\begin{array}{l}18(\mathrm{~F}) \\
16(\mathrm{M})\end{array}$ & Aesthetic & NR & $\begin{array}{l}\text { National } \\
\text { International }\end{array}$ & $\begin{array}{l}\text { Semi- } \\
\text { structured } \\
\text { interview. }\end{array}$ & $\begin{array}{l}\text { "Exploring } \\
\text { relation between } \\
\text { gymnasts" }\end{array}$ & $\begin{array}{l}\text { Teams and groups develop shared } \\
\text { norms of what is appropriate for } \\
\text { weight and shape. Older team } \\
\text { members avoid talking about body } \\
\text { dissatisfaction and pathological } \\
\text { eating attitudes to protect younger } \\
\text { team members from modelling such } \\
\text { behaviours. }\end{array}$ & + \\
\hline $\begin{array}{l}\text { Francisco et } \\
\text { al. }\end{array}$ & 2012 & Portugal & $\begin{array}{l}14.90 \text { years } \\
\text { (SD: NR) } \\
\text { Range: } 12-17\end{array}$ & $\begin{array}{l}11(\mathrm{~F}) \\
11(\mathrm{M})\end{array}$ & Aesthetic & NR & $\begin{array}{l}\text { National } \\
\text { International } \\
\text { (Gymnasts); } \\
\text { Dancers from } \\
\text { professional } \\
\text { dance school }\end{array}$ & $\begin{array}{l}\text { Focus } \\
\text { groups }\end{array}$ & "Peers" & $\begin{array}{l}\text { Dancers: Peers identified as key } \\
\text { risk factor for the development of } \\
\text { disordered eating. Two sub-themes; } \\
\text { "negative comments about weight } \\
\text { and body image" and "competitive } \\
\text { comparisons" } \\
\text { Gymnasts: Peers identified as key } \\
\text { protective factor against } \\
\text { development of disordered eating. } \\
\text { One subtheme: "Low } \\
\text { competitiveness". } \\
\text { "Peers seem to have much less } \\
\text { influence among gymnasts than } \\
\text { among dancers". }\end{array}$ & ++ \\
\hline
\end{tabular}


Table 2. Continued

\begin{tabular}{|c|c|c|c|c|c|c|c|c|c|c|c|}
\hline Author & Year & Country & Mean Age & $\begin{array}{l}\mathbf{N} \\
(\mathbf{M} / \mathbf{F})\end{array}$ & $\begin{array}{l}\text { Sport } \\
\text { Category }\end{array}$ & $\begin{array}{l}\text { Time in } \\
\text { sport }\end{array}$ & $\begin{array}{l}\text { Competition } \\
\text { level }\end{array}$ & Method & Key theme & Key Findings & $\begin{array}{l}\text { NICE } \\
\text { rating }\end{array}$ \\
\hline $\begin{array}{l}\text { Hausenblas } \\
\& \text { Carron }\end{array}$ & 2000 & America & $\begin{array}{l}20.99 \text { years } \\
\text { (SD: } 2.12) \\
\text { Range: NR }\end{array}$ & $\begin{array}{l}62(\mathrm{~F}) \\
69(\mathrm{M})\end{array}$ & $\begin{array}{l}\text { Ball game } \\
\text { Aesthetic } \\
\text { Power } \\
\text { Weight- } \\
\text { class }\end{array}$ & NR & University & $\begin{array}{l}\text { Open-ended } \\
\text { survey }\end{array}$ & $\begin{array}{l}\text { "Positive" } \\
\text { "Negative" }\end{array}$ & $\begin{array}{l}35.48 \% \text { of females and } 28.98 \% \text { of } \\
\text { males reported positive teammate } \\
\text { influences. } 11.29 \% \text { of females and } \\
8.69 \% \text { of males reported negative } \\
\text { teammate influences. Teammates } \\
\text { influenced quality and quantity of } \\
\text { food ingested, eating habits and/or } \\
\text { routines, psychological concerns } \\
\text { surrounding eating, weight/ body } \\
\text { shape consequences of dieting. } \\
\text { Teammates have a greater influence } \\
\text { on eating rather than dieting } \\
\text { behaviours. }\end{array}$ & + \\
\hline $\begin{array}{l}\text { Kroshus et } \\
\text { al. }\end{array}$ & 2014 & America & $\begin{array}{l}19.78 \text { years } \\
\text { (SD: } 1.03) \\
\text { Range: } 18-22\end{array}$ & $35(\mathrm{~F})$ & Endurance & NR & University & $\begin{array}{l}\text { Semi- } \\
\text { structured } \\
\text { interview. }\end{array}$ & $\begin{array}{l}\text { Communication } \\
\text { approaches }\end{array}$ & $\begin{array}{l}\text { Team 1: (1) Explicitly and pre- } \\
\text { emptively establish healthy team } \\
\text { eating norms; (2) Talk to the person } \\
\text { directly; (3) Captain takes the issue to } \\
\text { the assistant coach. } \\
\text { Team 2: (1) Do nothing. }\end{array}$ & ++ \\
\hline $\begin{array}{l}\text { Smith \& } \\
\text { Ogle }\end{array}$ & 2006 & America & $\begin{array}{l}16.25 \text { years } \\
(\mathrm{SD}: \mathrm{NR}) \\
\text { Range: } 15-18\end{array}$ & $8(\mathrm{~F})$ & Endurance & NR & High school & $\begin{array}{l}\text { In-depth } \\
\text { interviews/ } \\
\text { observations }\end{array}$ & $\begin{array}{l}\text { "Athlete-athlete } \\
\text { interactions" }\end{array}$ & $\begin{array}{l}\text { Sub theme: "Fat talk": Athletes were } \\
\text { either "fat talk challengers" or "fat } \\
\text { talkers". } \\
\text { Sub theme: "Deferential Avoidance". } \\
\text { Athletes avoided discussion of a very } \\
\text { thin teammate so as not to hurt her } \\
\text { feelings. }\end{array}$ & ++ \\
\hline $\begin{array}{l}\text { Smart \& } \\
\text { Bisogni }\end{array}$ & 2001 & America & $\begin{array}{l}\text { NR } \\
\text { Range:18-23 }\end{array}$ & $10(\mathrm{M})$ & Ball game & $12-13$ years & University & $\begin{array}{l}\text { Semi- } \\
\text { structured } \\
\text { interviews/ } \\
\text { observations }\end{array}$ & "Peer influence" & $\begin{array}{l}\text { Teammates were identified as a key } \\
\text { influence on athletes' food choices } \\
\text { through peer modelling and } \\
\text { competition for playing time. }\end{array}$ & ++ \\
\hline
\end{tabular}


Teammate influences on athletes' eating attitudes and behaviours

Table 2. Continued

\begin{tabular}{|c|c|c|c|c|c|c|c|c|c|c|c|}
\hline Author & Year & Country & Mean Age & $\begin{array}{l}\mathbf{N} \\
(M / F)\end{array}$ & $\begin{array}{l}\text { Sport } \\
\text { Category }\end{array}$ & $\begin{array}{l}\text { Time in } \\
\text { sport }\end{array}$ & $\begin{array}{l}\text { Competition } \\
\text { level }\end{array}$ & Method & Key theme & Key Findings & $\begin{array}{l}\text { NICE } \\
\text { rating }\end{array}$ \\
\hline $\begin{array}{l}\text { Stickler et } \\
\text { al. }\end{array}$ & 2016 & America & $\begin{array}{l}19.40 \text { years } \\
\text { (SD: } 1.30) \\
\text { Range: } 18-22\end{array}$ & $10(\mathrm{~F})$ & Endurance & $\begin{array}{l}80 \% 5 \\
\text { years } \\
10 \% 3-5 \\
\text { years } \\
10 \% 1-3 \\
\text { years }\end{array}$ & University & $\begin{array}{l}\text { Semi- } \\
\text { structured } \\
\text { interviews }\end{array}$ & $\begin{array}{l}\text { "Family and other } \\
\text { people" }\end{array}$ & $\begin{array}{l}\text { Teammates were listed as a key } \\
\text { source of nutritional information. }\end{array}$ & + \\
\hline Stirling et al. & 2011 & Canada & $\begin{array}{l}\text { NR } \\
\text { Range: } 18-25\end{array}$ & $37(\mathrm{~F})$ & $\begin{array}{l}\text { Power } \\
\text { Ball game } \\
\text { Aesthetic } \\
\text { Endurance }\end{array}$ & $\begin{array}{l}15-45 \\
\text { hours/ } \\
\text { week }\end{array}$ & $\begin{array}{l}\text { Mixed } \\
\text { competitive } \\
\text { levels }\end{array}$ & $\begin{array}{l}\text { Semi- } \\
\text { structured } \\
\text { interviews }\end{array}$ & $\begin{array}{l}\text { "Enabling/ } \\
\text { perpetuating } \\
\text { factors" }\end{array}$ & $\begin{array}{l}\text { Sub themes: "Competition" and } \\
\text { "Social comparison". Athletes } \\
\text { compared their physique to their } \\
\text { teammates. Competitions amongst } \\
\text { teammates to be the thinnest and have } \\
\text { the most prominent bones. }\end{array}$ & + \\
\hline $\begin{array}{l}\text { Stirling \& } \\
\text { Kerr }\end{array}$ & 2012 & Canada & $\begin{array}{l}20.10 \text { years } \\
\text { (SD: NR) } \\
\text { Range: } 18-25\end{array}$ & $17(\mathrm{~F})$ & $\begin{array}{l}\text { Ball game } \\
\text { Aesthetic } \\
\text { Endurance } \\
\text { Power }\end{array}$ & $\begin{array}{l}14-45 \\
\text { hours/ } \\
\text { week }\end{array}$ & $\begin{array}{l}\text { Mixed } \\
\text { competitive } \\
\text { levels }\end{array}$ & $\begin{array}{l}\text { Semi- } \\
\text { structured } \\
\text { interviews }\end{array}$ & $\begin{array}{l}\text { "Pressure/ } \\
\text { comments to lose } \\
\text { weight" }\end{array}$ & $\begin{array}{l}\text { Pressures to achieve or maintain a } \\
\text { low body weight were perceived to } \\
\text { stem from the enablement and } \\
\text { encouragement from teammates. } \\
\text { Competitiveness with teammates } \\
\text { extended beyond athletic } \\
\text { performances and into weight loss } \\
\text { and body fat. }\end{array}$ & ++ \\
\hline $\begin{array}{l}\text { Voelker et } \\
\text { al. }\end{array}$ & 2018 & America & $\begin{array}{l}18.45 \text { years } \\
\text { (SD: } 4.15)\end{array}$ & $29(\mathrm{M})$ & Aesthetic & $\begin{array}{l}\text { Mean: } \\
11.26 \\
\text { years } \\
\text { (SD:5.47) }\end{array}$ & $\begin{array}{l}\text { National } \\
\text { International }\end{array}$ & $\begin{array}{l}\text { Open-ended } \\
\text { survey } \\
\text { questions }\end{array}$ & $\begin{array}{l}\text { "Important } \\
\text { others" } \\
\text { (sub-theme, } \\
\text { "peers") }\end{array}$ & $\begin{array}{l}73 \% \text { reported important others as a } \\
\text { source of weight related pressure, } \\
41 \% \text { of these specifically reported } \\
\text { peers to be a source of weight related } \\
\text { pressure. Peer pressure manifested } \\
\text { via appearance comparisons. }\end{array}$ & + \\
\hline
\end{tabular}

